\title{
A Multi-Electron Transporting Layer for Efficient Perovskite Solar Cells
}

\author{
Kritsada Hongsith 1,2,3, Vasan Yarangsi 1,2,3 , Sukrit Sucharitakul 1,2,3, Surachet Phadungdhitidhada 1,2,3, \\ Athipong Ngamjarurojana $1,2,3$ (D) and Supab Choopun $1,2,3, *$ (D) \\ 1 Department of Physics and Materials Science, Faculty of Science, Chiang Mai University, \\ Chiang Mai 50200, Thailand; kritsada354@gmail.com (K.H.); vasan.yarangsi@gmail.com (V.Y.); \\ sukrit.sucharitakul@cmu.ac.th (S.S.); surelity@gmail.com (S.P.); ngamjarurojana@yahoo.com (A.N.) \\ 2 Research Center in Physics and Astronomy, Faculty of Science, Chiang Mai University, \\ Chiang Mai 50200, Thailand \\ 3 Thailand Center of Excellence in Physics, Ministry of Higher Education, Science, Research and Innovation, \\ 328 Si Ayutthaya Road, Bangkok 10400, Thailand \\ * Correspondence: supab99@gmail.com; Tel.: +66-819-512-669
}

check for updates

Citation: Hongsith, K.; Yarangsi, V.; Sucharitakul, S.; Phadungdhitidhada, S.; Ngamjarurojana, A.; Choopun, S. A Multi-Electron Transporting Layer for Efficient Perovskite Solar Cells. Coatings 2021, 11, 1020. https:// doi.org/10.3390/coatings11091020

Academic Editor: Alessandro Latini

Received: 19 July 2021

Accepted: 23 August 2021

Published: 25 August 2021

Publisher's Note: MDPI stays neutral with regard to jurisdictional claims in published maps and institutional affiliations.

Copyright: (c) 2021 by the authors. Licensee MDPI, Basel, Switzerland. This article is an open access article distributed under the terms and conditions of the Creative Commons Attribution (CC BY) license (https:// creativecommons.org/licenses/by/ $4.0 /)$.

\begin{abstract}
In this work, a multi-electron transporting layer (ETL) for efficient perovskite solar cells is investigated. The multi-ETL consists of five conditions including $\mathrm{SnO}_{2}, \mathrm{SnO}_{2} / \mathrm{SnO}_{\mathrm{x}}, \mathrm{TiO}_{2}, \mathrm{TiO}_{2} / \mathrm{SnO}_{2}$, and $\mathrm{TiO}_{2} / \mathrm{SnO}_{2} / \mathrm{SnO}_{\mathrm{x}}$. The best performance of PSC devices is found in the $\mathrm{SnO}_{2} / \mathrm{SnO}_{\mathrm{x}}$ doublelayer and exhibits a power conversion efficiency equal to $18.39 \%$ higher than the device with a $\mathrm{TiO}_{2}$ single-layer of $14.57 \%$. This enhancement in efficiency can be attributed to a decrease in charge transport resistance $\left(R_{c t}\right)$ and an increase in charge recombination resistance $\left(R_{r e c}\right)$. In addition, $R_{c t}$ and $R_{r e c}$ can be used to explain the comparable power conversion efficiency (PCE) between a PSC with a $\mathrm{SnO}_{2} / \mathrm{SnO}_{\mathrm{x}}$ double-layer and a PSC with a triple-layer, which is due to the compensation effect of $R_{c t}$ and $R_{r e c}$ parameters. Therefore, $R_{c t}$ and $R_{r e c}$ are good parameters to explain the efficiency enhancement in PSC. Thus, the $R_{c t}$ and $R_{r e c}$ from the electrochemical impedance spectroscopy (EIS) technique is an easy and alternative way to obtain information to understand and characterize the multi-ETL on PSC.
\end{abstract}

Keywords: perovskite solar cell; charge transfer resistance; electrochemical impedance spectroscopy; electron transporting layer; multi-layer

\section{Introduction}

Recently, the perovskite solar cell (PSC), as a new type of solar cell, has become an excellent photoelectric converter due to its low-cost and high-efficiency ability to harvest solar energy [1-7]. Currently, the efficiency of perovskite solar cells has increased up to $25.5 \%$ [8]. Typically, the structure of a perovskite solar cell mainly consists of three parts: an electron transporting layer (ETL), a perovskite layer, and a hole transporting layer (HTL). Recently, metal oxide wide-band-gap semiconductors such as titanium dioxide $\left(\mathrm{TiO}_{2}\right)$, zinc oxide $(\mathrm{ZnO})$, etc., have gained attraction for PSC applications as the charge transporting layer [9-14]. This is because of their high mobility, good energy alignment, and use of low-temperature processes [15-17]. However, the energy conversion efficiency of PSCs using metal oxide is quite volatile, due to the effect of many factors that depend on the structure of PSCs, such as morphology or thickness of metal oxide in the charge transporting layer [18-20]. Thus, many techniques have been used to investigate and study the charge transport resistance $\left(R_{c t}\right)$ and charge recombination resistance $\left(R_{r e c}\right)$ of PSCs with metal oxide in the charge transporting layer. One of the interesting techniques is electrochemical impedance spectroscopy (EIS).

EIS is one of the techniques for characterizing the electrical properties of materials and interfaces with conducting electrodes. This technique has been widely used to obtain 
information of carrier dynamical processes in the interfaces of layers [21-24]. EIS is a frequency-domain measurement method using the application of a small sinusoidal AC perturbation. The impedance measurements are recorded as a wide frequency sweep at a single disturbance amplitude. The most common spectral representations are impedance spectra, namely Nyquist and Bode plots. The resistor and capacitor results are separated by EIS according to process kinetics. In the Nyquist diagram, the complex negative segments are plotted against the real portion of the impedance, with the frequency as an implicit variable. This technique has been applied with relative success in the perovskite solar cells field because multiple effects occur simultaneously.

This EIS measurement technique is generally applied to study electron transporting layers. For example, $\mathrm{H}$. Yi et al. [25] modified the electron transporting layer by using $\mathrm{SnO}_{2}$ nanoparticles, sol-gel $\mathrm{SnO}_{2}$, and bilayer $\mathrm{SnO}_{2}$. From the results, the bilayer $\mathrm{SnO}_{2}$ devices showed the highest efficiency compared with the reference single-layer device. The increase in PCE can be explained by decreases in current leakage, higher electron transfer, and trap state in interfacial recombination. For the EIS results, the bilayer $\mathrm{SnO}_{2} \mathrm{PSC}$ showed a lower charge transfer resistance explained by increasing charge extraction phenomena from perovskite to ETL. A. R. Pascoe et al. [26] have studied impedance spectroscopy in planar PSC devices through the characterization of cells by employing a variety of constituent layers. Comparing the characteristic EIS time constants with time-resolved photoluminescence and open-circuit voltage decay, this work provides an empirical basis for understanding the impedance spectrum in planar PSCs.

In this work, a multi-electron transporting layer for efficient perovskite solar cells is investigated. The multi-layer ETL is composed of a $\mathrm{TiO}_{2}$ compact layer, a $\mathrm{SnO}_{2}$ layer, and is covered by a thin-film $\mathrm{SnO}_{x}$ layer by the sputtering method. The enhancement in efficiency is discussed in terms of charge transfer resistance, charge recombination resistance, and electron lifetime in PSCs that can be simply derived from EIS spectra.

\section{Experimental Details}

\subsection{Multi-ETL Preparation}

The multi-ETL was prepared in the following manner. First, the glass substrate was used and the fluorine-doped tin oxide (FTO) was patterned using zinc powder and a solution of hydrochloric acid $(\mathrm{HCl})$ and deionized (DI) water mixtures. Next, the FTO substrate was cleaned using a solution of detergents (Alconox). After that the solution was changed using DI water, acetone, and isopropanol, each in $15 \mathrm{~min}$, respectively, and all solutions were placed in a sonicator machine. After that, the FTO glass substrate was dried using nitrogen gas. Next, treatment on the surface of the FTO glass substrate was completed using UV ozone cleaner for $15 \mathrm{~min}$. Then, the multi-ETL was modified; a sequential step for the multi-ETL is summarized in Figure 1a. The $\mathrm{TiO}_{2}$ compact (CP) layer was prepared using titanium diisopropoxide bis (acetylacetonate) in absolute ethanol at a volumetric ratio of 1:7. The FTO substrate was coated with the mixture solution using spin coating deposition at $6000 \mathrm{rpm}$ for spin speed for $30 \mathrm{~s}$ and annealed at $500{ }^{\circ} \mathrm{C}$ for $1 \mathrm{~h}$. $\mathrm{SnO}_{2}$ films were prepared by using a precursor solution of $\mathrm{SnCl}_{2} \cdot 2 \mathrm{H}_{2} \mathrm{O}$ in ethanol $(0.1 \mathrm{M})$ at $4000 \mathrm{rpm} 30 \mathrm{~s}$ by spin coating and was annealed at $180{ }^{\circ} \mathrm{C}$ for $1 \mathrm{~h}$. Finally, the $\mathrm{SnO}_{\mathrm{x}}$ layer was coated using the DC magnetron sputtering technique at a power of $60 \mathrm{~W}$ for $5 \mathrm{~s}$ and annealed at $180^{\circ} \mathrm{C}$ for $1 \mathrm{~h}$. 
(a)

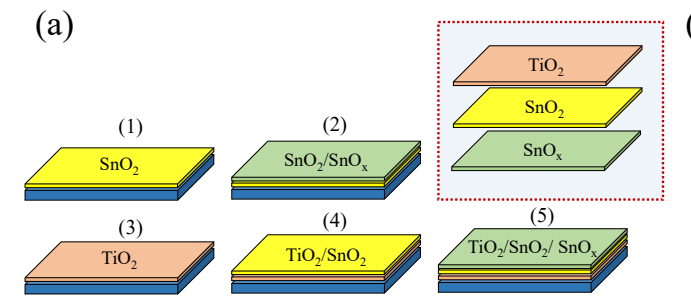

(b)

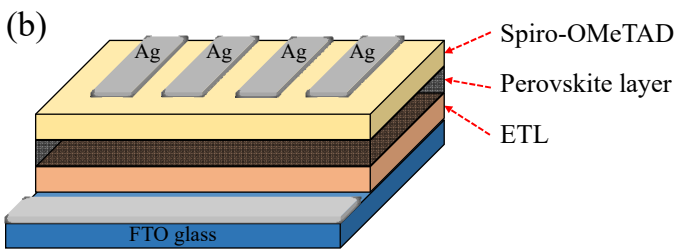

(c) $\mathrm{E}(\mathrm{eV})$

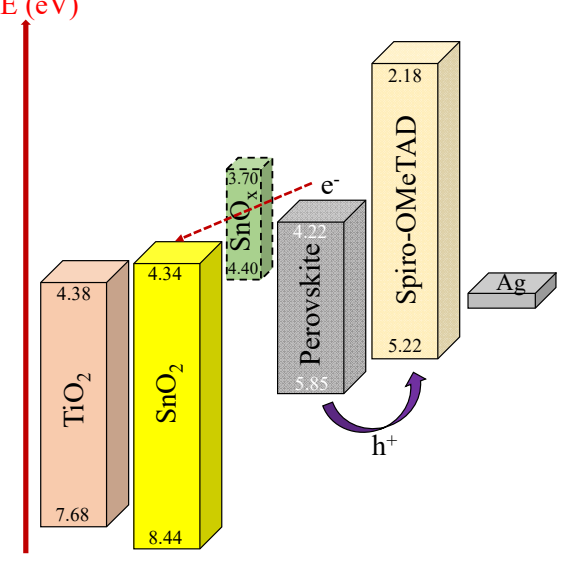

Figure 1. Schematic diagram of: (a) modified sequential thickness of ETL, (b) structure, and (c) energy band diagram of n-i-p perovskite solar cell.

\subsection{Device Fabrication}

The perovskite solutions were prepared in the following manner. First, the mixed cation halide perovskite layer was prepared using concentration for $1.1 \mathrm{M}$ of lead iodide $\left(\mathrm{PbI}_{2}\right), 1 \mathrm{M}$ of Formamidinium iodide (FAI), $0.02 \mathrm{M}$ of methylammonium bromide (MABr), $0.075 \mathrm{M}$ of cesium iodide ( $\mathrm{CsI})$, and $0.22 \mathrm{M}$ of lead (II) bromide $\left(\mathrm{PbBr}_{2}\right)$. All materials were mixed in a solution of DMF and DMSO at a 4:1 volume ratio and the last step was stirring at $70{ }^{\circ} \mathrm{C}$ for $2 \mathrm{~h}$. The hole transporting layer (HTL) using the Spiro-OMeTAD solution was prepared similarly to our previous work [27] by mixing Spiro-OMeTAD $72 \mathrm{mg}$, 4-tert-butyl pyridine $28.8 \mu \mathrm{L}$, and Li-TFSI solution $17.5 \mu \mathrm{L}$ (Li-TFSI $520 \mathrm{mg}$ in $1 \mathrm{~mL}$ of anhydrous acetonitrile) in $1 \mathrm{~mL}$ of chlorobenzene (CB).

The device's structure and principle of perovskite solar cell consisting of (FTO/ETL/ Perovskite/Spiro-OMeTAD/Ag) are shown in Figure 1b,c. The numbers in Figure 1c represent the energy level of conduction and valence band in each layer obtained from $[27,28]$. The perovskite layer was prepared using a one-step deposition method in a homemade nitrogen glove box with a controlled relative humidity of about $\mathrm{RH} 10 \%$ at room temperature used for preparing perovskite films. The perovskite solution was dropped on ETL by two-step spin rate. The first spin rate was $1000 \mathrm{rpm}$ for $10 \mathrm{~s}$ and the second step was $4000 \mathrm{rpm}$ for $25 \mathrm{~s}$. For the second spin rate, $350 \mu \mathrm{L}$ of chlorobenzene was dropped as an antisolvent to remove excess perovskite solution. After that, the device was annealed at $100{ }^{\circ} \mathrm{C}$ for $40 \mathrm{~min}$ and cooled down to room temperature. Later, the layer of HTL was prepared using Spiro-OMeTAD precursor solution covered on the perovskite layer using a spin coating technique for $4000 \mathrm{rpm}$ for $30 \mathrm{~s}$. Lastly, the top of the device was coated with the Ag films for back contact of PSC using thermal evaporation.

The thickness of the ETL is an important parameter for PSC performance. The thickness on this work is applied based on our previous work and other reported work [27,28]. The thickness of $\mathrm{SnO}_{2}$ is about $145 \mathrm{~nm}, \mathrm{SnO}_{\mathrm{x}}$ is about $10 \mathrm{~nm}$, and $\mathrm{TiO}_{2}$ is in the order of $50 \mathrm{~nm}$.

\subsection{Characterization of Films and Device}

For the measurement of the photovoltaic characteristics of PSC, we used a solar light simulation of $100 \mathrm{~mW} / \mathrm{cm}^{2}$ (AM1.5) with an Ossila Solar Cell I-V Test System (AutomatedS211 (T2003B) with built-in software), which has an active area of $0.04 \mathrm{~cm}^{2}$. Open-circuit voltage decay (OCVD) was used to study the charge dynamics of the PSCs. Moreover, the photoluminescence spectra of PSC were measured using a photoluminescence spectrometer with a nitrogen laser wavelength of $337.1 \mathrm{~nm}$ as an excitation source. Then, the electrochemical impedance spectroscopy was measured by a HIOKI 3522-50 LCR Hi tester. 


\section{Results and Discussion}

\subsection{Photovoltaic Performance of Perovskite Solar Cells}

Generally, the characteristic parameters of PSCs consist of the short-circuit photocurrent density $\left(J_{s c}\right)$, the open-circuit voltage $\left(V_{o c}\right)$, the fill factor of the cell $(F F)$, and the intensity of incident light $\left(P_{\text {in }}\right)$. Current density-voltage $(\mathrm{J}-\mathrm{V})$ characteristics of fabricated $\mathrm{n}$-i-p heterojunction PSCs of all conditions are measured under standard illumination of $100 \mathrm{~mW} / \mathrm{cm}^{2}$ (AM1.5); this is shown in Figure 2, with the photovoltaic parameters summarized in Table 1. It is found that the PSC devices fabricated with $\mathrm{SnO}_{2} / \mathrm{SnO}_{\mathrm{x}}$ in ETL exhibit the highest $P C E$ of $18.39 \%$ (compared to the device fabricated with $\mathrm{TiO}_{2}$ compact layer only of $14.57 \%$ ). The increase in PCE can be described in terms of an increase in $J_{s c}$ and FF. In addition, the $\mathrm{SnO}_{2} / \mathrm{SnO}_{\mathrm{x}}$ double-layer exhibits the highest $P C E$ due to the fabrication of a $\mathrm{p}-\mathrm{n}$ junction, which can be explained by the formation of built-in potential and a built-in electric field, resulting in low charge transfer resistance and high charge recombination resistance, as reported in our previous work [27]. In addition, the surface morphology of ETL looks similar, as seen in our previous work and other reported work $[27,28]$, and it has a smaller impact on the device performance, which can be seen from the close value of the current density for all conditions of ETL.
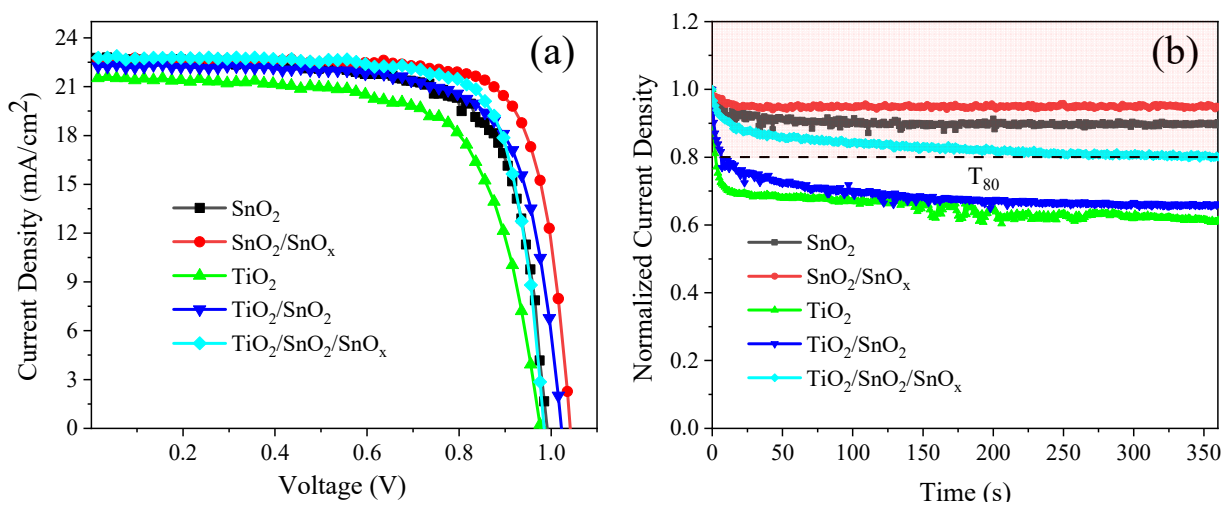

Figure 2. (a) Photovoltaic performance and (b) stability of current density of the perovskite solar cells with the different film multi-layers of ETL.

Table 1. Photovoltaic parameters of PSCs fabricated with the different conditions of ETL.

\begin{tabular}{|c|c|c|c|c|c|c|}
\hline Device & $V_{o c}(\mathrm{~V})$ & $J_{s c}\left(\mathrm{~mA} / \mathrm{cm}^{2}\right)$ & $F F$ & PCE (\%) & $R_{s h}(\Omega)$ & $R_{S}(\Omega)$ \\
\hline $\mathrm{SnO}_{2}$ & $\begin{array}{c}0.99 \\
(0.97 \pm 0.02)\end{array}$ & $\begin{array}{c}22.70 \\
(21.85 \pm 0.93)\end{array}$ & $\begin{array}{c}73.17 \\
(70.74 \pm 2.65)\end{array}$ & $\begin{array}{c}16.48 \\
(14.95 \pm 0.77)\end{array}$ & 2605.1 & 3.2 \\
\hline $\mathrm{SnO}_{2} / \mathrm{SnO}_{\mathrm{x}}$ & $\begin{array}{c}1.04 \\
(1.03 \pm 0.01)\end{array}$ & $\begin{array}{c}22.66 \\
(22.08 \pm 0.70)\end{array}$ & $\begin{array}{c}77.94 \\
(76.70 \pm 1.93)\end{array}$ & $\begin{array}{c}18.39 \\
(17.41 \pm 0.72)\end{array}$ & 3035.6 & 2.8 \\
\hline $\mathrm{TiO}_{2}$ & $\begin{array}{c}0.98 \\
(0.96 \pm 0.02)\end{array}$ & $\begin{array}{c}21.57 \\
(21.13 \pm 0.32)\end{array}$ & $\begin{array}{c}69.08 \\
(65.14 \pm 4.50)\end{array}$ & $\begin{array}{c}14.57 \\
(13.28 \pm 1.32)\end{array}$ & 1345.2 & 5.6 \\
\hline $\mathrm{TiO}_{2} / \mathrm{SnO}_{2}$ & $\begin{array}{c}1.02 \\
(1.00 \pm 0.01)\end{array}$ & $\begin{array}{c}22.23 \\
(22.23 \pm 0.44)\end{array}$ & $\begin{array}{c}73.36 \\
(70.80 \pm 2.09)\end{array}$ & $\begin{array}{c}16.68 \\
(15.82 \pm 0.75)\end{array}$ & 1435.9 & 3.6 \\
\hline $\mathrm{TiO}_{2} / \mathrm{SnO}_{2} / \mathrm{SnO}_{\mathrm{x}}$ & $\begin{array}{c}0.99 \\
(0.99 \pm 0.01)\end{array}$ & $\begin{array}{c}22.74 \\
(22.54 \pm 0.21)\end{array}$ & $\begin{array}{c}77.80 \\
(75.49 \pm 1.38)\end{array}$ & $\begin{array}{c}17.44 \\
(16.84 \pm 0.50)\end{array}$ & 2918.1 & 3.0 \\
\hline
\end{tabular}

The stability of the fabricated multi-ETL-based PSCs in the current density is shown in Figure $2 \mathrm{~b}$. The current density stability of the devices with no encapsulation is measured on a light simulation of $100 \mathrm{~mW} / \mathrm{cm}^{2}$ for $360 \mathrm{~s}$. Normally, $\mathrm{T}_{80}$ is defined as the time that the initial current density decays to $80 \%$. It can be seen that the stability of the $\mathrm{SnO}_{2} / \mathrm{SnO}_{\mathrm{x}}$ double-layer exhibits the highest stability, which is in agreement with the highest efficiency. It should be noted that PSCs with $\mathrm{TiO}_{2}$ and $\mathrm{TiO}_{2} / \mathrm{SnO}_{2}$ exhibit the lowest $\mathrm{T}_{80}$ of only about $20 \mathrm{~s}$. 
Until recently, the photovoltaic performance of PSCs depended on the number and thickness of ETL. Thus, the photoconversion properties of PSC will be studied in terms of optical and electrical properties, which are studied by photoluminescence spectroscopy $(\mathrm{PL})$, open-circuit voltage decay (OCVD), and electrochemical impedance spectroscopy (EIS), respectively.

\subsection{Investigation of Charge Transport of Perovskite Solar Cells}

The different multi-ETL conditions of PSCs in photoluminescence spectra are measured by PL for the investigation of photocharge transfer. Figure 3 shows the PL of the perovskite films prepared under different multi-ETL conditions. The $\mathrm{SnO}_{2} / \mathrm{SnO}_{\mathrm{x}}$ doublelayer exhibits the lowest PL intensity caused by the higher photocharge transfer from the perovskite layer to ETL than the other conditions. The higher photocharge transfer of the $\mathrm{SnO}_{2} / \mathrm{SnO}_{\mathrm{x}}$ double-layer condition can be explained by its lower radiative recombination and lower PL intensity.

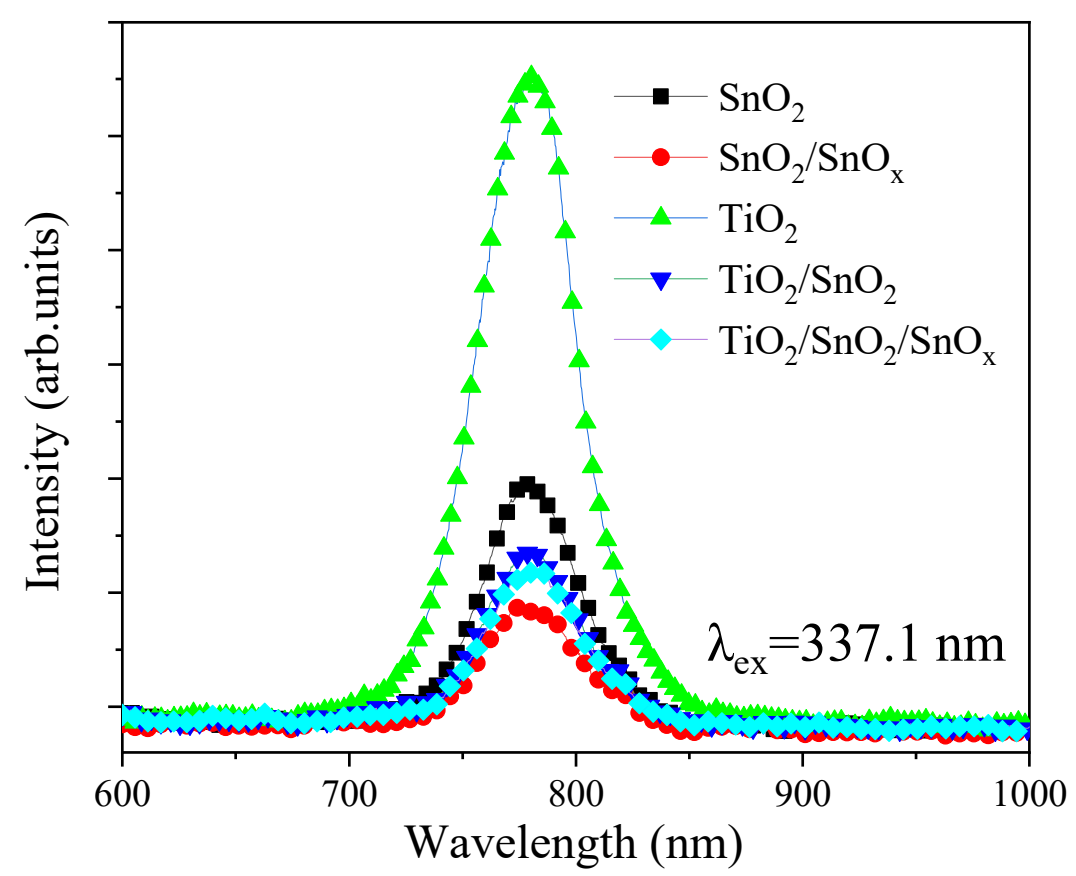

Figure 3. Photoluminescence spectra of the perovskite films prepared with the different conditions of ETL (excitation wavelength $=337.1 \mathrm{~nm}$ ).

To investigate charge recombination, $V_{o c}$ behavior is further studied by OCVD measurements of the PSCs, as shown in Figure 4. $V_{o c}$ decay is shown as a function of time when the light is turned off. The OCVD spectra are fitted and calculated in Table 2. The fitting graph is presented using a biexponential relation

$$
V_{o c}=A_{1} e^{\left(-\frac{t}{\tau_{1}}\right)}+A_{2} e^{\left(-\frac{t}{\tau_{2}}\right)}
$$

where $A_{1}$ and $A_{2}$ are time-independent coefficients of amplitude fractions for each decay component and $\tau_{1}$ and $\tau_{2}$ are the decay times of fast and slow components, respectively. The results are given in Table 2. $A_{1}{ }^{*}$ and $A_{2}{ }^{*}$ are normalized coefficients obtained from a relation. The longer charge transfer lifetime of PSCs with the multi-ETL rather than the single-ETL can also be seen. 


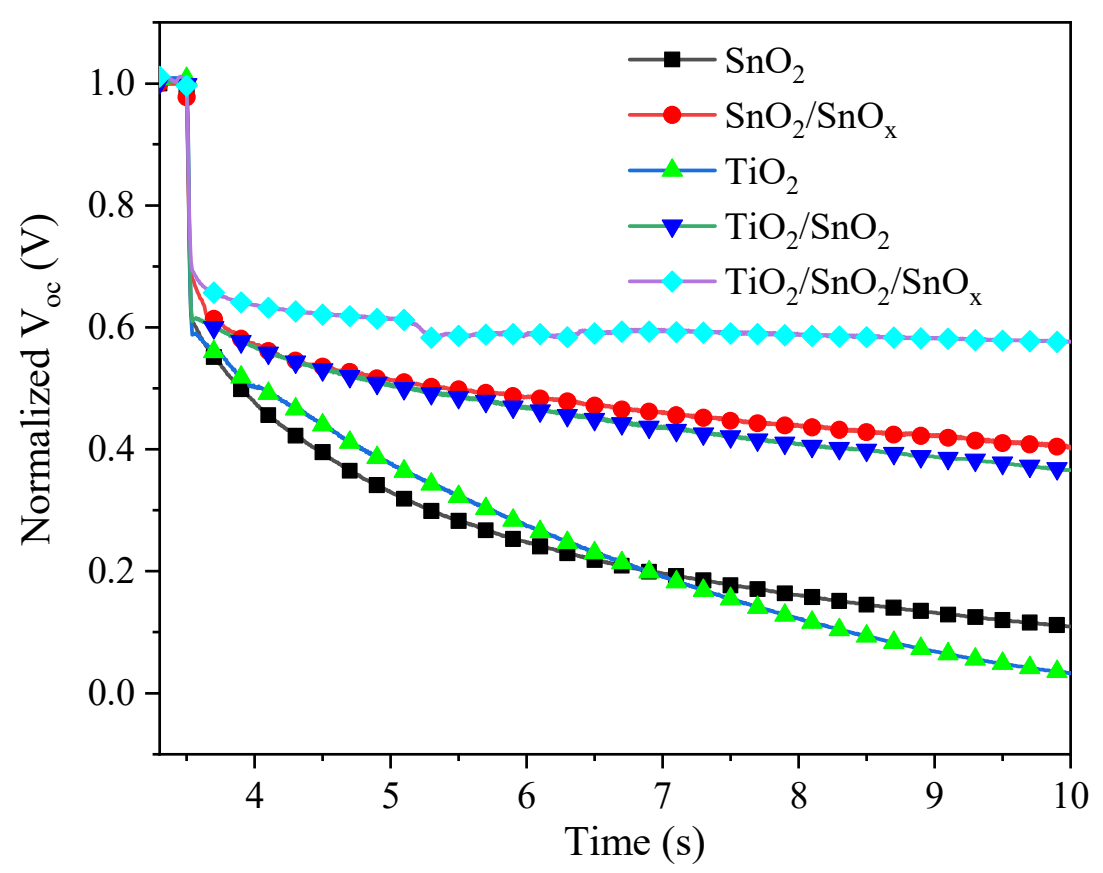

Figure 4. Voc decay of PSCs with the different conditions of ETL as a function of time after turning off the light.

Table 2. OCVD fitted parameters from Equation (1) for PSCs with the different conditions of ETL. $A_{1}^{*}$ and $A_{2}{ }^{*}$ are normalized coefficients obtained from a relation.

\begin{tabular}{cccccc}
\hline Device & $\boldsymbol{A}_{\mathbf{1}}{ }^{*}$ & $\boldsymbol{\tau}_{\mathbf{1}}(\mathbf{s})$ & $\boldsymbol{A}_{\mathbf{2}}{ }^{*}$ & $\boldsymbol{\tau}_{\mathbf{2}}(\mathbf{s})$ & $\boldsymbol{\tau}_{\text {average }}(\mathbf{s})$ \\
\hline $\mathrm{SnO}_{2}$ & 39.14 & 0.15 & 60.86 & 3.49 & 2.18 \\
$\mathrm{SnO}_{2} / \mathrm{SnO}_{\mathbf{x}}$ & 43.90 & 0.18 & 56.10 & 15.44 & 8.74 \\
$\mathrm{TiO}_{2}$ & 24.60 & 0.08 & 75.40 & 4.07 & 3.09 \\
$\mathrm{TiO}_{2} / \mathrm{SnO}_{2}$ & 38.50 & 0.36 & 61.50 & 15.70 & 9.80 \\
$\mathrm{TiO}_{2} / \mathrm{SnO}_{2} / \mathrm{SnO}_{\mathbf{x}}$ & 48.91 & 0.18 & 51.09 & 33.64 & 17.27 \\
\hline
\end{tabular}

For the study of electrical properties, the electron transport, charge recombination, and electron lifetime are characterized by the electrochemical process in EIS. The frequency range used in EIS ranges from 100,000 $\mathrm{Hz}$ to $450 \mathrm{~Hz}$, with an AC amplitude under $100 \mathrm{~mW} / \mathrm{cm}^{2}$ solar light (light condition) and without light (dark condition). The recorded EIS spectra of Nyquist plots of different ETL are shown in Figure 5a,b for light and dark conditions, respectively. The parameters of EIS from the semicircle Nyquist plot are calculated and summarized in Table 3. In Figure 5a, a semicircle (a starting point is at high to low frequency) is observed for all conditions and can be fitted to an equivalent circuit, as seen in the inset. In this range of frequency, $R_{1}$ can represents the series resistance, including the contributions from FTO glass and metal electrode, and $R_{c t}$ represents the resistance due to the interface between ETL and the perovskite layer $[29,30]$. Thus, the effect on the multi-ETL can be investigated by monitoring the value of $R_{c t}$. In Table 3 , the PSCs with the $\mathrm{SnO}_{2} / \mathrm{SnO}_{\mathrm{x}}$ conditions exhibit the lowest value of the $R_{c t}$, resulting in the highest $P C E$. Moreover, the $\mathrm{TiO}_{2} \mathrm{CP}$ single-layer shows the largest semicircle compared with the other condition, and it exhibits the highest $R_{c t}$ and the lowest PCE. Moreover, the charge recombination resistance $\left(R_{r e c}\right)$, which can be obtained under the dark conditions in Figure $5 b$, is related to the recombination sites at the interface of the ETL/perovskite layer, where the higher value represents a smaller chance of carriers being recombined. The PSC with $\mathrm{TiO}_{2} / \mathrm{SnO}_{2} / \mathrm{SnO}_{\mathrm{x}}$ under dark conditions demonstrated the largest $R_{\text {rec }}$. The electron 
lifetime $(\tau)$ can be calculated by Bode phase plots, which are written in terms of angular frequency or frequency as in Equation (2),

$$
\tau=\frac{1}{\omega_{\max }}=\frac{1}{2 \pi f_{\max }}
$$

where $\omega_{\max }$ is the maximum angular frequency and $f_{\max }$ is the maximum frequency (the data value can be obtained from the Bode phase plots at the frequency peak in the middle highest spectrum). Figure 6 shows the frequency peak for the PSC of all devices under dark conditions. It was found that the $f_{\max }$ of PSCs under the $\mathrm{SnO}_{2} / \mathrm{SnO}_{\mathrm{x}}$ condition changed to a lower frequency compared with the other conditions. Thus, the higher $\tau$ value suggests a longer electron lifetime. From EIS spectra, it should be noted that $R_{c t}$ can be derived from the light condition, but $R_{r e c}$ and electron lifetime can be derived from the dark condition.
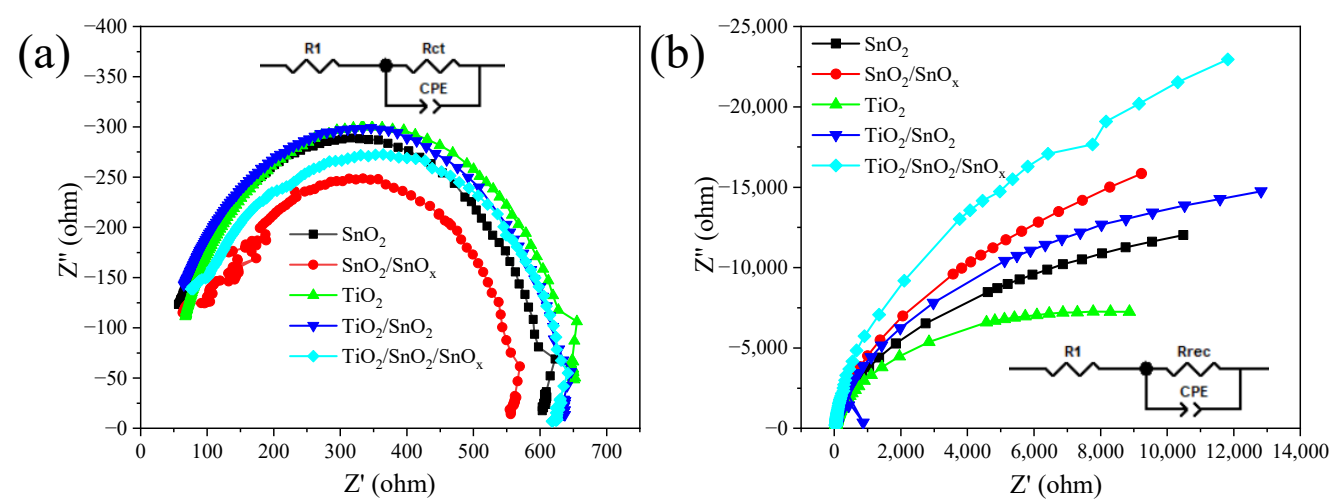

Figure 5. Nyquist plots of PSCs fabricated with the different conditions of ETL at: (a) light condition and (b) dark condition.

Table 3. Electrochemical parameters fabricated with the different conditions of ETL calculated from EIS analysis.

\begin{tabular}{cccccc}
\hline Device & $\boldsymbol{R}_{\mathbf{1}}(\boldsymbol{\Omega})$ & $\boldsymbol{R}_{\boldsymbol{c t}}(\boldsymbol{\Omega})$ & $\boldsymbol{R}_{\text {rec }}(\mathbf{k} \boldsymbol{\Omega})$ & $f(\mathrm{~Hz})$ & $\boldsymbol{\tau}(\boldsymbol{\mu s})$ \\
\hline $\mathrm{SnO}_{2}$ & 7.5 & 598 & 24.6 & 13000 & 12.2 \\
$\mathrm{SnO}_{2} / \mathrm{SnO}_{\mathbf{x}}$ & 14.5 & 520 & 39.1 & 10000 & 15.9 \\
$\mathrm{TiO}_{2}$ & 8.5 & 631 & 16.3 & 19000 & 8.4 \\
$\mathrm{TiO}_{2} / \mathrm{SnO}_{2}$ & 10.8 & 620 & 31.0 & 11000 & 14.5 \\
$\mathrm{TiO}_{2} / \mathrm{SnO}_{2} / \mathrm{SnO}_{\mathbf{x}}$ & 13.6 & 610 & 58.2 & 11000 & 14.5 \\
\hline
\end{tabular}

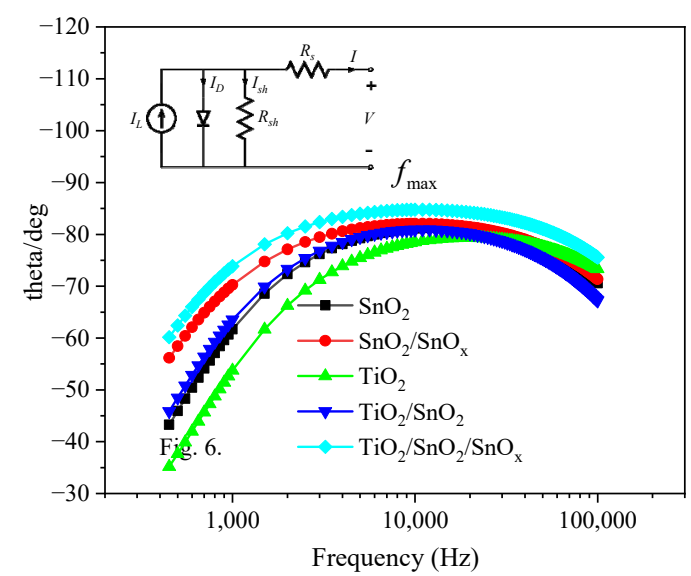

Figure 6. Bode phase plots of PSCs fabricated with the different conditions of ETL in dark condition and an equivalent circuit of solar cell in the inset. 


\subsection{Explaination of Efficiency Enhancement Due to Multi-ETL by EIS}

Enhancements in efficiency can be practically explained using $R_{c t}$ and $R_{r e c}$, as earlier discussed. Typically, the lower the $R_{c t}$, the higher the PCE, and the higher the $R_{r e c}$, the higher the PCE. The lowest $R_{c t}$ is observed in PSC with a $\mathrm{SnO}_{2} / \mathrm{SnO}_{\mathrm{x}}$ double-layer and the highest $R_{r e c}$ is differently observed in a PSC with a triple-layer. However, the PCE is comparable for the $\mathrm{SnO}_{2} / \mathrm{SnO}_{x}$ double-layer and triple-layer. The comparable PCE for both cases can be explained using Equation (3) with an equivalent circuit, as shown in an inset of Figure 6:

$$
I=I_{L}-I_{D}-I_{s h}=I_{L}-I_{0} \exp \left[\frac{q\left(V+I R_{s}\right)}{n k T}\right]-\frac{V+I R_{s}}{R_{s h}}
$$

where $I$ is the cell output current, $I_{L}$ is the light-generated current, $I_{D}$ is the dark current, $I_{s h}$ is the shunt current, $V$ is the voltage across the cell terminals, $T$ is the temperature, $q$ and $k$ are constants, $n$ is the ideality factor, $R_{s}$ is the cell series resistance, and $R_{s h}$ is the cell shunt resistance.

This equation can be divided into three terms. The first term represents the light current or photocurrent and can be related to $R_{c t}$. The second term represents the dark current and can be related to $R_{r e c}$. The third term represents shunt current and can be related to $R_{s h}$ and $R_{S}$.

As such, the PCE of the $\mathrm{SnO}_{2} / \mathrm{SnO}_{\mathrm{x}}$ double-layer, which has the lowest $R_{c t}$ but lower $R_{r e c}$ than that of the triple-layer, exhibits a comparable PCE to the PSC with a triple-layer, as the $R_{c t}$ and $R_{r e c}$ parameters create a compensation effect. It can be seen that $R_{c t}$, which can be derived from the light condition, and $R_{r e c}$, which can be derived from the dark condition, are suitable parameters to explain the efficiency enhancement in PSCs.

Normally, current information in light and dark conditions can be separately observed by PL and OCVD, respectively. However, it can be seen that EIS provides an easy and alternative way to obtain both light and dark conditions in one technique, which is useful information for explaining the enhancement in efficiency that characterizes PSCs.

\section{Conclusions}

The multi-ETLs in PSCs have been designed and fabricated to investigate the photoconversion performance of EIS. It is found that the PSC devices fabricated with a $\mathrm{SnO}_{2} / \mathrm{SnO}_{\mathrm{x}}$ double-layer in ETL exhibit the highest PCE of $18.39 \%$. The efficiency enhancement can be discussed in terms of charge transport, charge recombination, and electron lifetime in PSCs. The enhancement in efficiency can be attributed to a decrease in $R_{c t}$ and an increase in $R_{\text {rec }}$. In addition, $R_{c t}$ and $R_{\text {rec }}$ can be used to explain the comparable PCE between PSCs with a $\mathrm{SnO}_{2} / \mathrm{SnO}_{\mathrm{x}}$ double-layer and those with a triple-layer, which is due to the compensation effect of the $R_{c t}$ and $R_{r e c}$ parameters. Therefore, $R_{c t}$, which can be derived from the light condition, and $R_{r e c}$, which can be derived from the dark condition, are appropriate parameters to explain the enhancement in efficiency in PSCs. Thus, $R_{c t}$ and $R_{r e c}$ show that the electrochemical impedance spectroscopy technique is an easy and alternative way to obtain information to understand and characterize multi-ETLs in PSCs.

Author Contributions: Conception and design of the study, K.H., V.Y. and S.C.; acquisition of data, K.H. and V.Y.; analysis and/or interpretation of data, K.H., S.S., A.N., S.P. and S.S.; drafting the manuscript, K.H., S.C. and S.S.; revising the manuscript critically for important intellectual content, K.H. and S.C. All authors have read and agreed to the published version of the manuscript.

Funding: This research was funded by Chiang Mai University.

Institutional Review Board Statement: Not applicable.

Informed Consent Statement: Not applicable.

Data Availability Statement: Not applicable.

Acknowledgments: This research work was partially supported by Chiang Mai University. 
Conflicts of Interest: The authors declare no conflict of interest.

\section{References}

1. Kojima, A.; Teshima, K.; Shirai, Y.; Miyasaka, T. Organometal halide perovskites as visible-light sensitizers for photovoltaic cells. J. Am. Chem. Soc. 2009, 131, 6050-6051. [CrossRef]

2. Zhu, H.; Liu, Y.; Eickemeyer, F.T.; Pan, L.; Ren, D.; Ruiz-Preciado, M.A.; Carlsen, B.; Yang, B.; Dong, X.; Wang, Z.; et al. Tailored amphiphilic molecular mitigators for stable perovskite solar cells with 23.5\% efficiency. Adv. Mater. 2020, 32, 1907757. [CrossRef]

3. Zhen, C.; Wu, T.; Chen, R.; Wang, L.; Liu, G.; Cheng, H.M. Strategies for modifying $\mathrm{TiO}_{2}$ based electron transport layers to boost perovskite solar cells. ACS Sustain. Chem. Eng. 2019, 7, 4586-4618. [CrossRef]

4. Li, X.; Bi, D.; Yi, C.; Decoppet, J.D.; Luo, J.; Zakeeruddin, S.M.; Hagfeldt, A.; Gratzel, M. A vacuum flash-assisted solution process for high-efficiency large-area perovskite solar cells. Science 2016, 353, 58-61. [CrossRef]

5. Jiang, Q.; Chu, Z.; Wang, P.; Yang, X.; Liu, H.; Wang, Y.; Yin, Z.; Wu, J.; Zhang, X.; You, J. Planar-structure perovskite solar cells with efficiency beyond 21\%. Adv. Mater. 2017, 29, 1703852. [CrossRef] [PubMed]

6. Zhu, N.; Qi, X.; Zhang, Y.; Liu, G.; Wu, C.; Wang, D.; Guo, X.; Luo, W.; Li, X.; Hu, H.; et al. High efficiency (18.53\%) of flexible perovskite solar cells via the insertion of potassium chloride between $\mathrm{SnO}_{2}$ and $\mathrm{CH}_{3} \mathrm{NH}_{3} \mathrm{PbI}_{3}$ layers. ACS Appl. Energy Mater. 2019, 2, 3676-3682. [CrossRef]

7. Xie, J.; Huang, K.; Yu, X.; Yang, Z.; Xiao, K.; Qiang, Y.; Zhu, X.; Xu, L.; Wang, P.; Cui, C.; et al. Enhanced electronic properties of $\mathrm{SnO}_{2}$ via electron transfer from graphene quantum dots for efficient perovskite solar cells. ACS Nano 2017, 11, 9176-9182 [CrossRef]

8. National Renewable Energy Laboratory. Best Research-Cell Efficiency Chart. Available online: https://www.nrel.gov/pv/cellefficiency.html (accessed on 26 July 2021).

9. Shin, S.S.; Lee, S.J.; Seok, S.I. Metal oxide charge transport layers for efficient and stable perovskite solar cells. Adv. Funct. Mater. 2019, 29, 1900455. [CrossRef]

10. Xiong, L.; Guo, Y.; Wen, J.; Liu, H.; Yang, G.; Qin, P.; Fang, G. Review on the application of $\mathrm{SnO}_{2}$ in perovskite solar cells. Adv. Funct. Mater. 2018, 28, 1802757. [CrossRef]

11. Duong, T.T.; Hoang, P.H.; Nhan, L.T.; Duong, L.V.; Nam, M.H.; Tuan, L.Q. Multistep spin-spray deposition of large-grain-size $\mathrm{CH}_{3} \mathrm{NH}_{3} \mathrm{PbI}_{3}$ with bilayer structure for conductive-carbon-based perovskite solar cells. Curr. Appl. Phys. 2019, 19, 1266-1270. [CrossRef]

12. Sharma, S.; Soleimanioun, N.; Kaur, R.; Rani, M.; Tripathi, S.K. Comparative study of the effect of Mg, Zn and Ag dopants on properties of titanium dioxide as mesoporous ETL for photovoltaic application. Mater. Chem. Phys. 2021, 257, 123730. [CrossRef]

13. Chen, Y.; Meng, Q.; Zhang, L.; Han, C.; Gao, H.; Zhang, Y.; Yan, H. SnO 2 -based electron transporting layer materials for perovskite solar cells: A review of recent progress. J. Energy Chem. 2019, 35, 144-167. [CrossRef]

14. Chen, Q.; Guo, W.; Ke, J.C.R.; Mokhtar, M.Z.; Wang, D.; Jacobs, J.; Thomas, A.G.; Curry, R.J.; Liu, Z. Ultrafast and scalable laser-induced crystallization of titanium dioxide films for planar perovskite solar cells. Sol. RRL 2020, 5, 2000562. [CrossRef]

15. Jiang, Q.; Zhang, X.; You, J. SnO 2 : A wonderful electron transport layer for perovskite solar cells. Small 2018, $14,1801154$. [CrossRef] [PubMed]

16. Wang, Y.; Djuriši'c, A.B.; Chen, W.; Liu, F.; Cheng, R.; Feng, S.P.; Ng, A.M.C.; He, Z. Metal oxide charge transport layers in perovskite solar cells-optimising low temperature processing and improving the interfaces towards low temperature processed, efficient and stable devices. J. Phys. Energy 2021, 3, 012004. [CrossRef]

17. Xie, H.; Yin, X.; Liu, J.; Guo, Y.; Chen, P.; Que, W.; Wang, G.; Gao, B. Low temperature solution-derived $\mathrm{TiO}_{2}-\mathrm{SnO}_{2}$ bilayered electron transport layer for high performance perovskite solar cells. Appl. Surf. Sci. 2019, 464, 700-707. [CrossRef]

18. Ouyang, D.; Huang, Z.; Choy, W.C.H. Solution-Processed Metal Oxide Nanocrystals as Carrier Transport Layers in Organic and Perovskite Solar Cells. Adv. Funct. Mater. 2019, 29, 1804660. [CrossRef]

19. Yang, G.; Chen, C.; Yao, F.; Chen, Z.; Zhang, Q.; Zheng, X.; Ma, J.; Lei, H.; Qin, P.; Xiong, L.; et al. Effective carrier-concentration tuning of $\mathrm{SnO}_{2}$ quantum dot electron-selective layers for high-performance planar perovskite solar cells. Adv. Mater. 2018, 30, 1706023. [CrossRef]

20. Noh, Y.W.; Lee, J.H.; Jin, I.S.; Park, S.H.; Jung, J.W. Enhanced efficiency and ambient stability of planar heterojunction perovskite solar cells by using organic-inorganic double layer electron transporting material. Electrochim. Acta 2019, 294, 337-344. [CrossRef]

21. Lee, H.B.; Kumar, N.; Ovhal, M.M.; Kim, Y.J.; Song, Y.M.; Kang, J.W. Dopant-free, amorphous-crystalline heterophase SnO 2 electron transport bilayer enables $>20 \%$ efficiency in triple-cation perovskite solar cells. Adv. Funct. Mater. 2020, 30, 2001559. [CrossRef]

22. Chen, X.; Shirai, Y.; Yanagida, M.; Miyano, K. Effect of light and voltage on electrochemical impedance spectroscopy of perovskite solar cells: An empirical approach based on modified randles circuit. J. Phys. Chem. C 2019, 123, 3968-3978. [CrossRef]

23. Bernal, L.C.; Terrón, S.R.; Riquelme, A.; Boix, P.; Idígoras, J.; Seró, I.M.; Anta, J.A. impedance analysis of perovskite solar cells: A case study. J. Mater. Chem. A 2019, 7, 12191-12200. [CrossRef]

24. Hailegnaw, B.; Sariciftci, N.S.; Scharber, M.C. Impedance spectroscopy of perovskite solar cells: Studying the dynamics of charge carriers before and after continuous operation. Phys. Status Solidi A 2020, 217, 2000291. [CrossRef]

25. Yi, H.; Wang, D.; Mahmud, M.A.; Haque, F.; Upama, M.B.; Xu, C.; Duan, L.; Uddin, A. Bilayer SnO 2 as electron transport layer for highly efficient perovskite solar cells. ACS Appl. Energy Mater. 2018, 1, 6027-6039. [CrossRef] 
26. Pascoe, A.R.; Duffy, N.W.; Scully, A.D.; Huang, F.; Cheng, Y.B. Insights into planar $\mathrm{CH}_{3} \mathrm{NH}_{3} \mathrm{PbI}_{3}$ perovskite solar cells using impedance spectroscopy. J. Phys. Chem. C 2015, 119, 4444-4453. [CrossRef]

27. Yarangsi, V.; Hongsith, K.; Sucharitakul, S.; Ngamjarurojana, A.; Tuantranont, A.; Kumnorkaew, P.; Zhao, Y.; Phadungdhitidhada, S.; Choopun, S. Interface modification of $\mathrm{SnO}_{2}$ layer using $\mathrm{p}-\mathrm{n}$ junction double layer for efficiency enhancement of perovskite solar cell. J. Phys. D Appl. Phys. 2020, 53, 505103. [CrossRef]

28. Tavakoli, M.M.; Giordano, F.; Zakeeruddin, S.M.; Grätzel, M. Mesoscopic oxide double layer as electron specific contact for highly efficient and UV stable perovskite photovoltaics. Nano Lett. 2018, 18, 2428-2434. [CrossRef]

29. Rong, Y.; Ku, Z.; Mei, A.; Liu, T.; Xu, M.; Ko, S.; Li, X.; Han, H. Hole-conductor-free mesoscopic $\mathrm{TiO}_{2} / \mathrm{CH}_{3} \mathrm{NH}_{3} \mathrm{PbI}_{3}$ heterojunction solar cells based on anatase nanosheets and carbon counter electrodes. J. Phys. Chem. Lett. 2014, 5, 2160-2164. [CrossRef]

30. Abdulrahim, S.M.; Ahmad, Z.; Bahadra, J.; Al-Thani, N.J. Electrochemical impedance spectroscopy analysis of hole transporting material free mesoporous and planar perovskite solar cells. Nanomaterials 2020, 10, 1635. [CrossRef] 